\title{
Dark Protein Synthesis: Physiological Response to Nutrient Limitation of a Natural Phytoplankton Population ${ }^{1}$
}

\author{
Satoru Taguchi ${ }^{2,3}$ and Edward A. Laws ${ }^{2}$
}

\begin{abstract}
Dark ${ }^{14} \mathrm{CO}_{2}$ incorporation into protein was determined from 24-hr incubations using size-fractionated natural phytoplankton populations from Kāne'ohe Bay, Hawai'i, enriched with either ammonium or ammonium plus phosphorus. Response to ammonium addition was maximum at an ammonium concentration of 3-4 $\mu \mathrm{M}$. Dark ${ }^{14} \mathrm{CO}_{2}$ assimilation was suppressed by addition of both ammonium and phosphorus, but percentage incorporation into protein was not significantly different from addition of ammonium alone. About $75 \pm 1 \%$ of the ${ }^{14} \mathrm{C}$ taken up by the cells was incorporated into either protein or low-molecular-weight intermediate compounds. Cells smaller than $10 \mu \mathrm{m}$ showed little response to nutrient additions. However, cells in the $10-$ to $35-\mu \mathrm{m}$ size fraction incorporated significantly more ${ }^{14} \mathrm{C}$ into protein when nutrients were added. $\mathrm{C}: \mathrm{N}$ ratios calculated from the percentage of ${ }^{14} \mathrm{C}$ incorporated into protein were most variable temporally in the 10 - to $35-\mu \mathrm{m}$ size group and least variable in the picoplankton $(0.2-2.0 \mu \mathrm{m})$. Nutrient limitation indices (NLIs) calculated from the quotient of $\mathrm{C}: \mathrm{N}$ ratios in control and nutrient-enriched cultures were not significantly different for the picoplankton and 2- to $10-\mu \mathrm{m}$ size fraction. The NLI for the 10- to $35-\mu \mathrm{m}$ size fraction was significantly lower and implied a modest degree of nutrient limitation. The results suggest that cells smaller than $10 \mu \mathrm{m}$ are growing at close to nutrient-saturated rates much of the time in Kāne'ohe Bay. However, larger cells appear to experience a significant degree of nutrient limitation at some times, particularly when chlorophyll $a$ concentrations are less than about $1 \mathrm{mg} \mathrm{m}^{-3}$. Dark protein synthesis appears to be a useful modification of previous methods based on the dark uptake of ${ }^{14} \mathrm{CO}_{2}$ for studying nutrient limitation.
\end{abstract}

Nitrogen-limited phytoplankton are known to take up ammonium rapidly in the dark as well as in the light (Goldman and Glibert 1983). In contrast to ammonium, nitrate uptake is light-dependent (MacIsaac and Dugdale 1972) for most phytoplankton, with

${ }^{1}$ SOEST contribution number 5232. Manuscript accepted 24 April 2000.

${ }^{2}$ Hawai'i Institute of Marine Biology and Department of Oceanography, School of Ocean and Earth Science and Technology, University of Hawai' $i$ at Mānoa, Honolulu, Hawai'i 96822.

${ }^{3}$ Current address: Department of Bioengineering, Faculty of Engineering, Soka University, 1-236 TangiCho, Hachiouji, Tokyo 192-8577, Japan.

Pacific Science (2001), vol. 55, no. 1:1-15

(C) 2001 by University of Hawaici Press

All rights reserved the exception of some dinoflagellates (Dortch and Maske 1982).

When ammonium is taken up in the dark, it may be incorporated into amino acids using carbon also assimilated in the dark (MortainBertrand et al. 1988). Dark ammonium uptake is accompanied by enhanced dark ${ }^{14} \mathrm{CO}_{2}$ assimilation by nitrogen-limited phytoplankton. The degree of enhancement of dark ${ }^{14} \mathrm{CO}_{2}$ assimilation may be a function of nitrogen limitation. This idea was suggested by Morris et al. (1971) and Yentsch et al. (1977) and later confirmed experimentally by Goldman and Dennett (1983). Glibert et al. (1985) and Cook et al. (1992, 1994) used this approach to study nutrient limitation of natural phytoplankton populations and symbiotic zooxanthellae, respectively. Ammonium enrichment in the dark led to significant $\mathrm{CO}_{2}$ uptake by the marine diatom Chaetoceros sim- 
plex regardless of whether the cultures were preconditioned with oxidized or reduced nitrogen (Goldman and Dennett 1986). Ammonium enrichment in the dark led to significant $\mathrm{CO}_{2}$ assimilation by the marine diatom Skeletonema costatum preconditioned with limited nitrogen (Granum and Myklestad 1999). The results to date indicate that the response of dark $\mathrm{CO}_{2}$ fixation to ammonium enrichment is a useful semiquantitative tool for studying phytoplankton nitrogen limitation, in the sense that it can be used to distinguish between no, moderate, and severe nitrogen limitation. Dodds and Priscu (1991) used the same approach to study nitrogen limitation of chemoautotrophic ammoniumoxidizing bacteria in fresh water.

Protein synthesis is known to occur at night (Cuhel et al. 1984). However dark protein synthesis as opposed to ${ }^{14} \mathrm{CO}_{2}$ uptake has never been related to nitrogen limitation. Because protein synthesis is directly related to the growth rate of phytoplankton (Goldman 1980, DiTullio and Laws 1986, Taguchi and Laws 1987), in this study we extended the use of dark ${ }^{14} \mathrm{CO}_{2}$ assimilation to study dark protein synthesis in size-fractionated phytoplankton populations to explore the degree of nitrogen limitation of growth rate. The method focuses on the metabolic incorporation of ${ }^{14} \mathrm{CO}_{2}$ into protein rather than the short-term flux of ammonium across the cell membrane and assimilation into soluble organic nitrogen. We used this approach because short-term ammonium uptake and growth are equal only in the steady state. They are often uncoupled in natural systems (Goldman and Glibert 1983).

The approach used here was to enrich natural phytoplankton populations with either ammonium or ammonium plus phosphorus and to observe the effect on the dark ${ }^{14} \mathrm{CO}_{2}$ incorporation into protein by different size classes. The work was carried out in Kāne'ohe Bay, Hawai'i, where previous studies related to nutrient limitation have been carried out (e.g., Taguchi and Laws 1987). We proposed a nutrient limitation index based on a ratio of $\mathrm{C}: \mathrm{N}$ in control populations to $\mathrm{C}: \mathrm{N}$ ratio in enriched samples. Applicability of the nutrient limitation index is examined to determine the status of ammonium limitation of phytoplankton growth in Kāne'ohe Bay.

\section{MATERIALS AND METHODS}

Water samples were taken monthly from a depth of $10 \mathrm{~cm}$ in Kāne'ohe Bay $\left(157^{\circ}\right.$ $47.2^{\prime} \mathrm{W}, 21^{\circ} 25.4^{\prime} \mathrm{N}$ ) from May 1988 to May 1989. Each water sample was prescreened through a $35-\mu \mathrm{m}$ nytex netting and transferred to an acid-cleaned 1-liter dark bottle. An initial set of experiments was used to explore the effect of varying the ratio of ammonium to phosphorus in the enrichments. The concentration of ammonium was varied from 0 to $20 \mu \mathrm{M}$ while the concentration of phosphate was kept at $1 \mu \bar{M}$. Based on these preliminary experiments, subsequent assays employed ammonium at a concentration of $3 \mu \mathrm{M}$ and phosphate at a concentration of $1 \mu \mathrm{M}$. The experimental design of the subsequent experiments involved three assays. One aliquot of each sample received no nutrient additions (control). A second subsample received ammonium at a final concentration of $3 \mu \mathrm{M}\left(+\mathrm{NH}_{4}\right)$. A third bottle received ammonium at a final concentration of $3 \mu \mathrm{M}$ and phosphorus at a final concentration of $1 \mu \mathrm{M}\left(+\mathrm{NH}_{4}+\mathrm{PO}_{4}\right)$. All samples were preincubated in the dark at $24^{\circ} \mathrm{C}$ for $24 \mathrm{hr}$. At the end of the preincubation all samples were inoculated with $100 \mu \mathrm{Ci}$ of $\mathrm{NaH}^{14} \mathrm{CO}_{3}$ and incubated for an additional $24 \mathrm{hr}$ in the dark. Duplicate 1-ml aliquots were taken from each bottle to determine the total activity of ${ }^{14} \mathrm{C}$. At the end of each incubation duplicate aliquots of $100 \mathrm{ml}$ were withdrawn from the bottles and filtered onto glass fiber filters (Whatman GF/F) to determine dark assimilation by the total phytoplankton community. The value obtained was always checked against the sum of the size-fractionated values as a cross-check on the calculations. Triplicate aliquots of a separate subsample were filtered consecutively through Nuclepore filters with nominal pore sizes of 10,2 , and $0.2 \mu \mathrm{m}$ for the size fractionation study. One of the three aliquots was taken for determination of total particulate activity, and two of the three aliquots were used to partition ${ }^{14} \mathrm{C}$ activity into separate organic fractions. Vol- 
umes of 200-500, 200-500, and $100 \mathrm{ml}$ were filtered through 10-, 2-, and 0.2- $\mu \mathrm{m}$ Nuclepore filters to determine filter blanks. All filters were stored in $1 \mathrm{ml}$ of $10 \% \mathrm{HCl}$ solution at $-20^{\circ} \mathrm{C}$ until further processing. Water samples for chlorophyll $a$ (chl $a$ ) analyses were taken at the beginning and the end of the incubation for total and size-fractionated pigment analysis. Duplicate aliquots were taken for the total chl $a$ sample. For the size fractionation study the volumes were identical to those used in the ${ }^{14} \mathrm{C}$ fractionation. The filters were immediately placed in plastic vials containing $100 \%$ acetone and stored at $-20^{\circ} \mathrm{C}$ until further processing. The filtrates from the pigment assays were used for nutrient analysis. They were stored at $-20^{\circ} \mathrm{C}$ until further processing.

A differential extraction technique (Morris et al. 1971) was used to partition the recently assimilated carbon between protein, polysaccharide plus nucleic acids (PNA), lipids, and low-molecular-weight intermediate compounds (INT). The details of the procedure were given by Taguchi and Laws (1987). Chl $a$ and pheopigments were determined on a fluorometer (Turner) using procedures recommended by Holm-Hansen et al. (1965).
All nutrient analyses were performed on a Technicon Autoanalyzer using the methods of Solorzano (1969) for ammonium, Wood et al. (1967) for nitrate plus nitrite, and Murphy and Riley (1962) for molybdate reactive phosphorus.

$\mathrm{C}: \mathrm{N}$ weight ratios were calculated from the equation (DiTullio and Laws 1986):

$$
\frac{\mathrm{C}}{\mathrm{N}}=\frac{(2.8)(100)}{\%{ }^{14} \mathrm{C} \text { in protein }}
$$

The nutrient limitation index was calculated from the ratio of the $\mathrm{C}: \mathrm{N}$ ratio of the control to the $\mathrm{C}: \mathrm{N}$ ratio of the samples enriched with ammonium or ammonium plus phosphorus.

A two-way analysis of variance was conducted.

\section{RESULTS}

Seventy-two $\pm 12 \%$ of the chl $a$ was found in cells larger than $2 \mu \mathrm{m}$ (Table 1). Previous work (Murphy 1972) has shown that in Kāne'ohe Bay these consist primarily of diatoms, including Chaetoceros spp. in particular. The chl $a$ concentration decreased by $35 \pm 17 \%$ during the incubations, probably

\section{TABLE}

Percentage of $\mathrm{Chl} a$ Accounted for by Each Size Fraction, Percentage ${ }^{14} \mathrm{C}$ Incorporation into Protein by Each Size Fraction, Total and Final $\mathrm{Chl} a$, and Percentage ${ }^{14} \mathrm{C}$ Incorporation into Protein by the Total Phytoplankton Community

\begin{tabular}{|c|c|c|c|c|c|c|c|c|c|}
\hline \multirow[b]{2}{*}{ Date } & \multicolumn{2}{|c|}{$10-35 \mu \mathrm{m}$} & \multicolumn{2}{|c|}{$2-10 \mu \mathrm{m}$} & \multicolumn{2}{|c|}{$0.2-2 \mu \mathrm{m}$} & \multicolumn{2}{|c|}{ Total Chl $a$} & \multirow[b]{2}{*}{ Protein } \\
\hline & $\mathrm{Chl} a$ & Protein & $\mathrm{Chl} a$ & Protein & Chl $a$ & Protein & $T_{0}$ & $\mathrm{~T}_{24}$ & \\
\hline 16 June 1988 & 14 & 33 & 49 & 49 & 37 & 50 & 1.7 & 1.0 & 46 \\
\hline 7 July 1988 & 10 & 25 & 50 & 59 & 40 & 61 & 1.8 & 0.99 & 57 \\
\hline 4 Aug. 1988 & 51 & 19 & 29 & 31 & 20 & 51 & 2.0 & 1.1 & 42 \\
\hline 8 Sept. 1988 & 52 & 40 & 28 & 56 & 20 & 57 & 1.8 & 0.95 & 56 \\
\hline 4 Oct. 1988 & 41 & 16 & 25 & 45 & 34 & 51 & 0.67 & 0.53 & 45 \\
\hline 1 Nov. 1988 & 29 & 21 & 30 & 48 & 41 & 62 & 0.73 & 0.50 & 57 \\
\hline 6 Dec. 1988 & 37 & 30 & 35 & 48 & 28 & 66 & 1.3 & 0.75 & 62 \\
\hline 10 Jan. 1989 & 25 & 29 & 42 & 55 & 33 & 60 & 1.3 & 0.99 & 57 \\
\hline 7 Feb. 1989 & 57 & 43 & 29 & 58 & 14 & 66 & 3.2 & 2.2 & 64 \\
\hline 8 Mar. 1989 & 18 & 34 & 39 & 49 & 43 & 45 & 1.4 & 0.81 & 44 \\
\hline 12 Apr. 1989 & 90 & 48 & 7 & 39 & 3 & 50 & 16 & 18 & 46 \\
\hline 3 May 1989 & 30 & 34 & 42 & 47 & 28 & 46 & 1.1 & 0.83 & 45 \\
\hline Average & 38 & 31 & 34 & 49 & 28 & 56 & 2.8 & 2.4 & 52 \\
\hline \pm S.D. & 22 & 9.7 & 12 & 8.0 & 12 & 7.7 & 4.2 & 4.9 & 7.8 \\
\hline
\end{tabular}




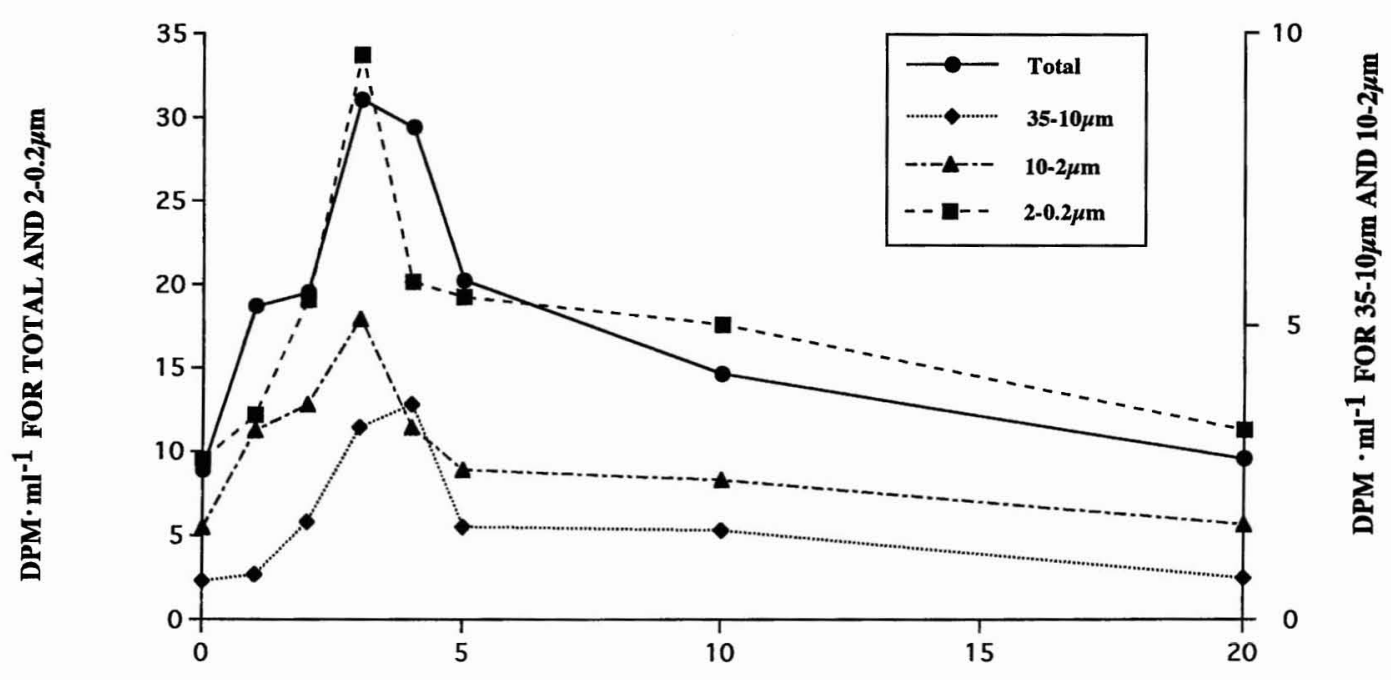

AMMONIA ADDED $(\boldsymbol{\mu M})$

Figure 1. Response of dark ${ }^{14} \mathrm{CO}_{2}$ assimilation to the concentration of ammonium added on 10 May 1988.

because of grazing by microzooplankton (Landry et al. 1984). Size distribution of the chl $a$ was essentially the same at the beginning and end of the incubations.

Typical results of the effect of added ammonium concentration on dark ${ }^{14} \mathrm{CO}_{2}$ uptake are shown in Figure 1. Most ${ }^{14} \mathrm{CO}_{2}$ was assimilated by the picoplankton, a result consistent with earlier work in Kāne'ohe Bay (Taguchi and Laws 1987) and in the equatorial Atlantic Ocean (Herbland et al. 1985). For all size fractions, dark ${ }^{14} \mathrm{CO}_{2}$ uptake consistently peaked at ammonium concentrations of 3-4 $\mu \mathrm{m}$. The simultaneous addition of ammonium and phosphate resulted in less ${ }^{14} \mathrm{CO}_{2}$ uptake than addition of ammonium by itself, and ${ }^{14} \mathrm{CO}_{2}$ assimilation peaked at ammonium concentrations of $2-5 \mu \mathrm{m}$ (Figure 2). The degree of depression of the ${ }^{14} \mathrm{CO}_{2}$ uptake peak was positively correlated with cell size, being 33,56 , and $75 \%$ in the case of the 0.2 - to $2.0-\mu \mathrm{m}$ (picoplankton), 2to $10-\mu \mathrm{m}$, and 10 - to $35-\mu \mathrm{m}$ size fractions, respectively.

Several patterns were apparent in the percentage of ${ }^{14} \mathrm{CO}_{2}$ incorporated into protein (Figure 3). First, the percentage was negatively correlated with cell size. The average percentage protein across all treatments was $57 \pm 7,51 \pm 10$, and $35 \pm 10 \%$ for the $0.2-$ to $2.0-\mu \mathrm{m}, 2$ - to $10-\mu \mathrm{m}$, and $10-$ to $35-\mu \mathrm{m}$ size fractions, respectively (Table 2 ). Second, the percentage of ${ }^{14} \mathrm{CO}_{2}$ incorporated into protein increased with the degree of nutrient enrichment. Across all cell sizes, the percentage protein averaged $45 \pm 9,47 \pm 9$, and $51 \pm 9 \%$ for the control, $+\mathrm{NH}_{4}$, and $+\mathrm{NH}_{4}+\mathrm{PO}_{4}$ treatments, respectively. Third, the sum of the percentage ${ }^{14} \mathrm{CO}_{2}$ incorporation into protein plus INT compounds was virtually constant at $75-76 \%$. In other words, any changes in percentage incorporation into protein were balanced by equal and opposite changes in the percentage incorporation into INT.

The $\mathrm{C}: \mathrm{N}$ ratios of the control cultures calculated from the equation averaged 10.0 $\pm 3.6,5.9 \pm 1.2$, and $5.1 \pm 0.7$ by weight for the 10 - to $35-\mu \mathrm{m}, 2$ - to $10-\mu \mathrm{m}$, and $0.2-$ to $2.0-\mu \mathrm{m}$ size fractions, respectively (Figure $4 A$ ). The $\mathrm{C}: \mathrm{N}$ ratios of the picoplankton showed the least temporal variability, with a coefficient of variation (CV) of only $14 \%$. The $C: N$ ratios of the $10-$ to $35-\mu$ m fraction showed the most temporal variability, with a $\mathrm{CV}$ of $36 \%$. There was no statistically sig- 


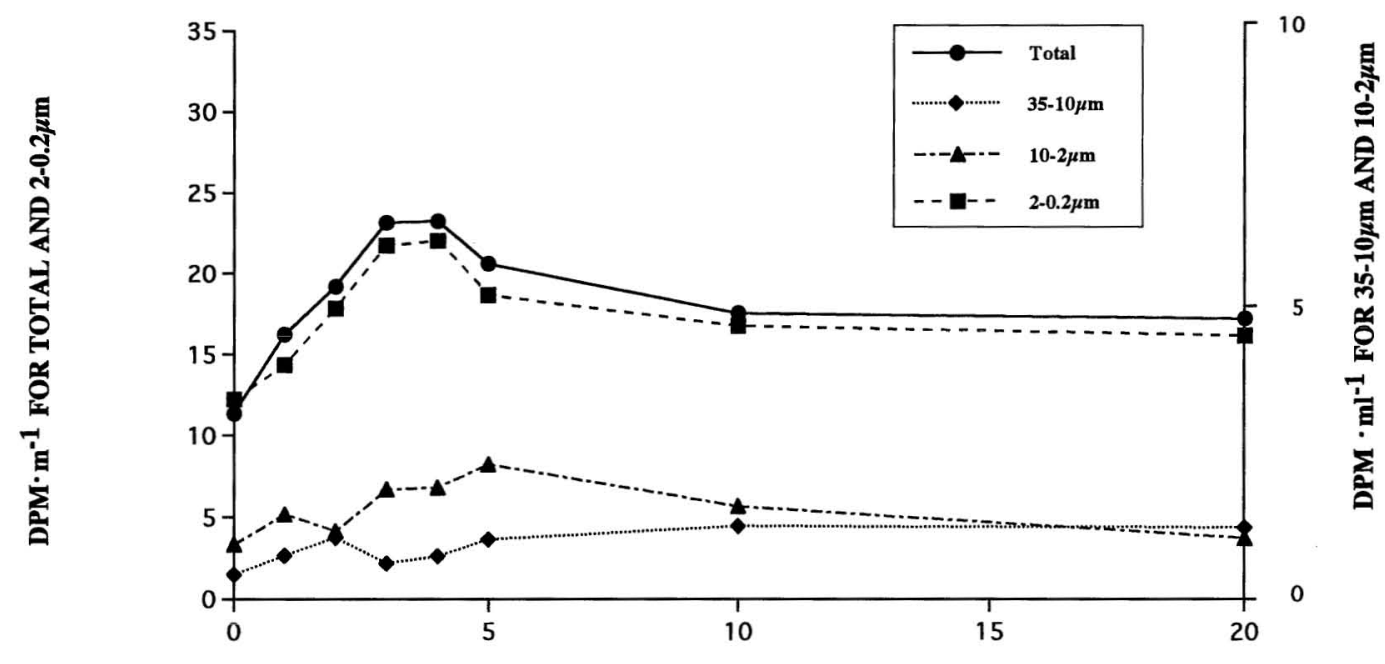

AMMONIA ADDED $(\boldsymbol{\mu} \mathbf{M})$

FiguRE 2. Response of dark ${ }^{14} \mathrm{CO}_{2}$ assimilation to the concentration of ammonium plus phosphorus added.

nificant correlation between the $\mathrm{C}: \mathrm{N}$ ratios of any of the size fractions and either phosphate or ammonium concentrations (Figure $4 B)$.

\section{DISCUSSION}

Several different methods have been used to study nitrogen limitation of phytoplankton growth. Potentially the most informative technique is the uptake of ${ }^{15} \mathrm{~N}$-labeled substrates (McCarthy 1980, Harrison 1983). This method can potentially provide the specific uptake of nitrogen for each species. At least in the past, several methodological problems have limited the usefulness of the ${ }^{15} \mathrm{~N}$ method. Before the development of highly sensitive analytical methods, the ${ }^{15} \mathrm{~N}$ labeled substrate was not a true tracer, because addition of the substrate at concentrations as low as $50 \mathrm{nM}$ significantly altered ambient nutrient concentrations in oligotrophic marine waters (Allen et al. 1996). Additional problems can occur as a result of substrate depletion during long incubations (MacIsaac and Dugdale 1969) and recycling of substrate in the incubation bottle ( $\mathrm{La}-$ Roche and Harrison 1987). For the most part these problems have been overcome with the use of relatively short-term incubations, corrections for isotope dilution (Laws 1984), and highly sensitive analytical methods that allow substrate additions to be made in tracer amounts (McCarthy et al. 1999). An additional concern is heterotrophic bacterial uptake of ammonium (Laws et al. 1985), which is a potential problem primarily in the 0.2 - to 2.0- $\mu \mathrm{m}$ size fraction.

Before the development of isotopic methods, nutrient enrichment experiments were the primary tool used to examine questions related to nutrient limitation (e.g., Menzel et al. 1963). This traditional approach or modifications thereof have been used to the present time, and the results have sometimes proven highly informative (Kolber et al. 1994, Lindley and Barber 1998). Potential problems with this approach include bottle confinement artifacts (Banse 1991) and the fact that the implications may be sensitive to the duration of the incubation. For example, ammonium enrichment dose not enhance ${ }^{14} \mathrm{CO}_{2}$ uptake immediately in the light (e.g., Thomas et al. 1976), but effects on ${ }^{14} \mathrm{CO}_{2}$ uptake are manifest after several hours of incubation (e.g., Healy 1979). 

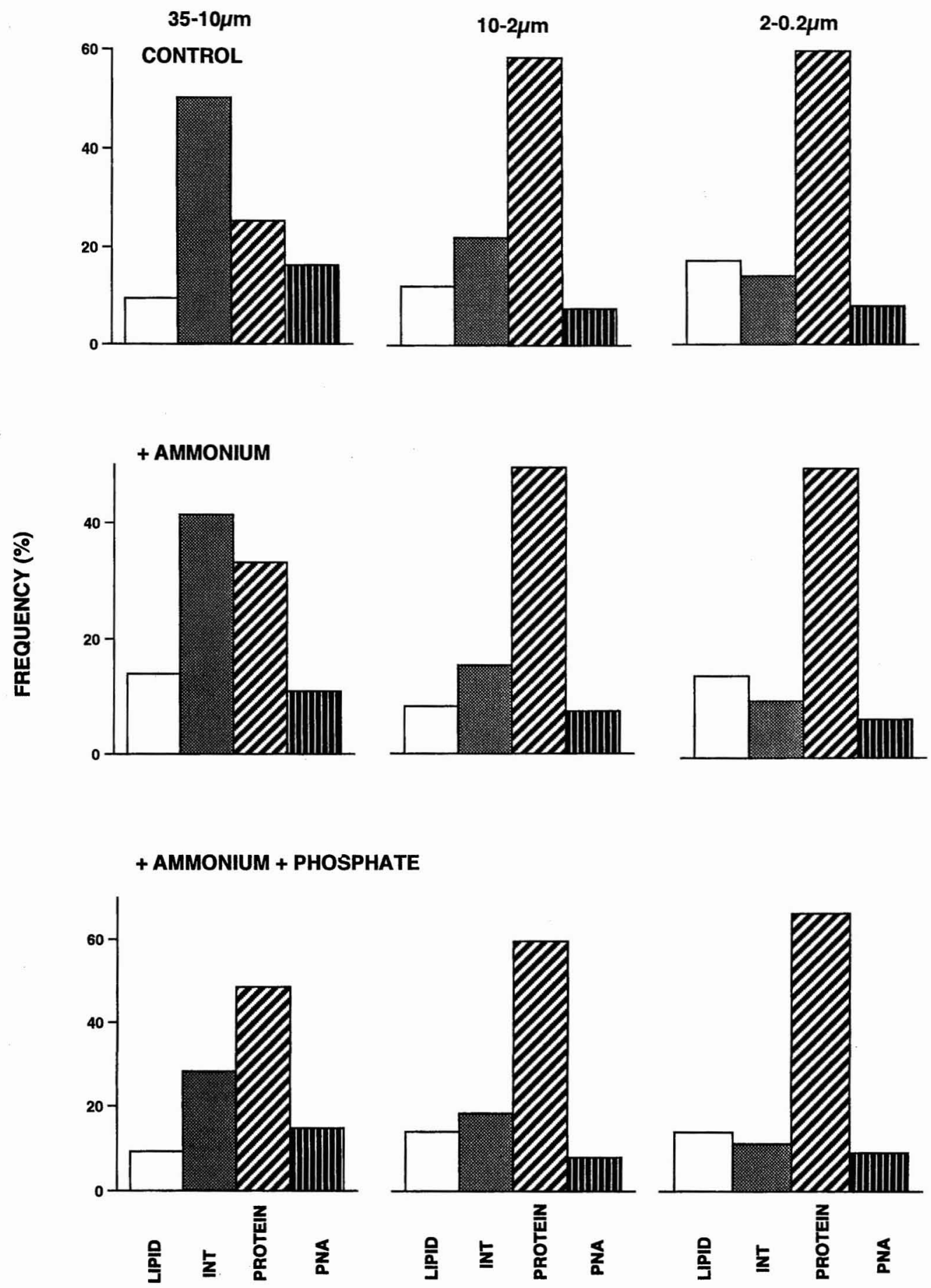

Figure 3. Relative distribution of ${ }^{14} \mathrm{CO}_{2}$ incorporation into lipids, low-molecular-weight intermediate compounds (INT), protein, and polysaccharide plus nucleic acids (PNA) for the 35 - to $10-\mu \mathrm{m}, 10$ - to $2-\mu \mathrm{m}$, and 2 - to $0.2-\mu \mathrm{m}$ size groups of natural phytoplankton population without nutrients and with $3 \mu \mathrm{M}$ of ammonium and $3 \mu \mathrm{M}$ of ammonium plus $1 \mu \mathrm{M}$ of phosphorus on 7 July 1988. 
TABLE 2

Annual Average of the Percentage of ${ }^{14} \mathrm{C}$ Incorporated into Lipids, Low-Molecular-Weight Intermediates (INT), Protein, and Polysaccharide + Nucleic Acids (PNA) during Monthly Dark Incubations in Kāne'ohe Bay

\begin{tabular}{lcccc}
\hline \hline Cell size & End Products & Control & $+\mathrm{NH}_{4}$ & $+\mathrm{NH}_{4}+\mathrm{PO}_{4}$ \\
\hline $10-35 \mu \mathrm{m}$ & Lipids & $15 \pm 4$ & $15 \pm 5$ & $14 \pm 4$ \\
& INT & $42 \pm 8$ & $42 \pm 10$ & $37 \pm 13$ \\
& Protein & $31 \pm 10$ & $35 \pm 9$ & $38 \pm 10$ \\
& PNA & $12 \pm 6$ & $10 \pm 5$ & $11 \pm 4$ \\
$2-10 \mu \mathrm{m}$ & Lipids & $16 \pm 2$ & $15 \pm 4$ & $16 \pm 5$ \\
& INT & $27 \pm 7$ & $26 \pm 13$ & $22 \pm 8$ \\
& Protein & $49 \pm 8$ & $8 \pm 12$ & $54 \pm 10$ \\
& PNA & $9 \pm 4$ & $19 \pm 2$ & 8 \\
$0.2-2 \mu \mathrm{m}$ & Lipids & $19 \pm 4$ & $18 \pm 4$ & $18 \pm 4$ \\
& INT & $20 \pm 6$ & $56 \pm 6$ & $15 \pm 3$ \\
& Protein & $56 \pm 8$ & $7 \pm 5$ & $70 \pm 7$ \\
& PNA & & & $7 \pm 5$ \\
\hline
\end{tabular}

Dortch et al. (1985) proposed use of the ratio of free amino acids to protein to determine the degree of nitrogen deficiency. This ratio may be an effective indicator of the nutritional status of phytoplankton cells, because nitrogen-deficient cells rapidly lose their free amino acids. However, application of this approach in the field is confounded by the contribution of nonphytoplankton to the measurements of free amino acids and protein.

Based on laboratory culture work with the diatom Cbaetoceros simplex, Goldman and Dennett (1986:498) proposed the use of the relatively simple and effective technique of measuring dark ${ }^{14} \mathrm{CO}_{2}$ uptake to determine the degree and form of nitrogen limitation of phytoplankton growth. They argued that long incubations led to reduced rates of dark ${ }^{14} \mathrm{CO}_{2}$ uptake and concluded, "concomitantly, the sensitivity of the assay was impaired considerably." Their argument, however, was based on experiments with a relatively high biomass of nitrogen (e.g., either 25 or $100 \mu \mathrm{M}$ of nitrogen) for one cultured species. To have enough signal from dark incubations of natural phytoplankton populations, particularly in oligotrophic waters, the activity of the ${ }^{14} \mathrm{C}$ spike must be high and/or the length of incubation should be longer than the 30-45 min used by Goldman and Dennett (1986). Glibert et al. (1985) applied the Goldman and Dennett (1986) technique to natural populations with $\operatorname{chl} a$ concentrations of $0.34-1.3 \mathrm{mg} \mathrm{m}^{-3}$. Based on 3-hr incubations, they concluded that dark ${ }^{14} \mathrm{CO}_{2}$ uptake can be used to infer the degree of nutrient limitation.

Rapid dark uptake of ammonium is accompanied by dark ${ }^{14} \mathrm{CO}_{2}$ assimilation, with the assimilated carbon being used to produce amino acids (Granum and Myklestad 1999). Eventually these amino acids are transformed into protein. From an examination of the pattern of accumulation of internal pools of inorganic nitrogen and free amino acids, Wheeler (1983) concluded that transport $>$ assimilation $>$ incorporation for diatoms and that transport $>$ assimilation $<$ incorporation for Cblorella and flagellates. The maximum transport rates for the latter species are higher than those for diatoms (Wheeler 1983). These observations suggest that assimilated nitrogen is more rapidly incorporated into protein by nondiatom species than by diatoms. This speculation is consistent with the lower rate of protein synthesis by the 10 - to $35-\mu \mathrm{m}$ size group in our studies (Figure 2). Microalgal $\mathrm{C}: \mathrm{N}$ ratios are positively correlated with growth rate under light-limited conditions and negatively correlated with growth rate under nutrient-limited conditions (Laws and Bannister 1980, Frenette et al. 1998). Based on previous studies in Kāne'ohe Bay, it is reasonable to assume that 


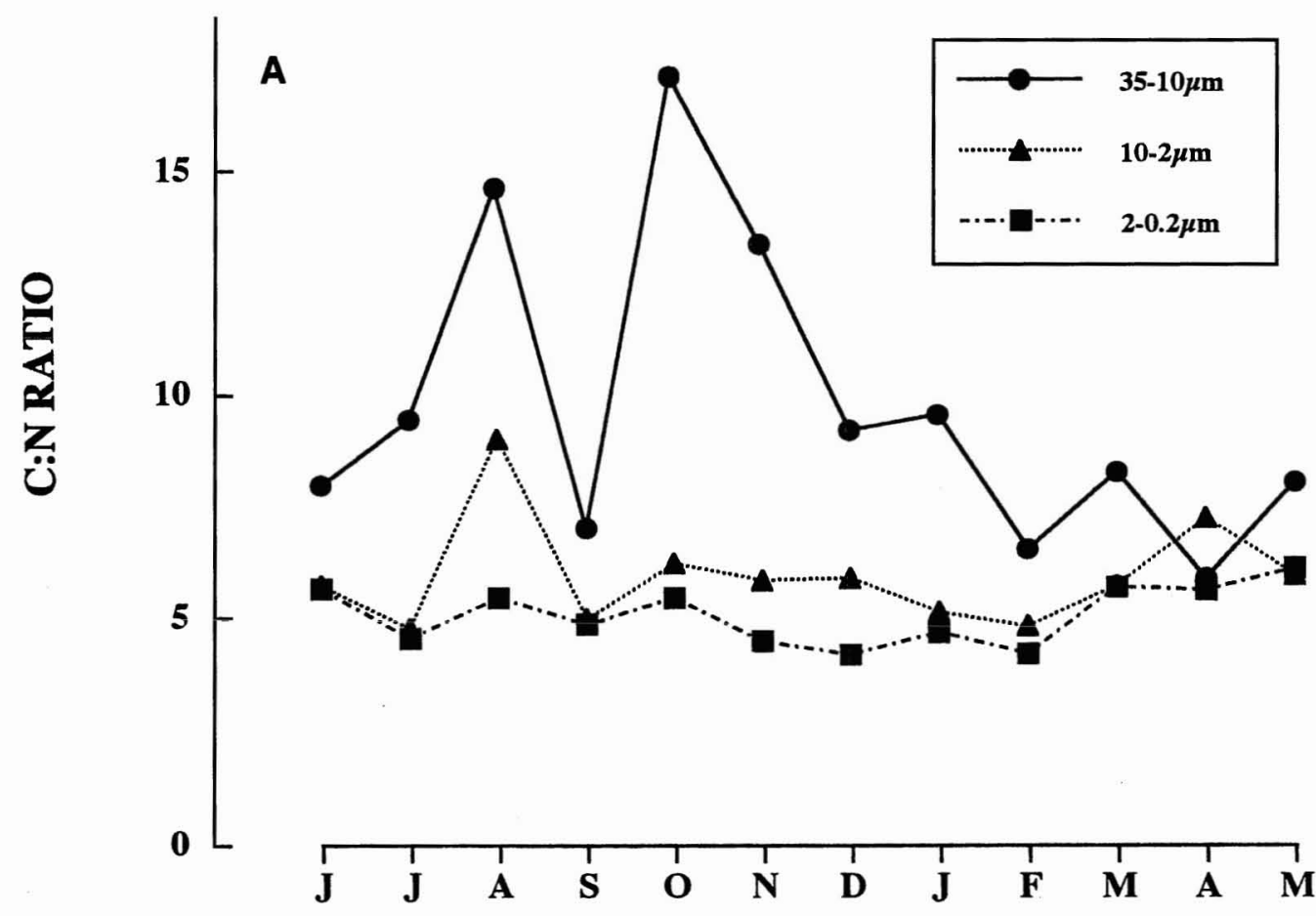

MONTH

FIGURE 4. Seasonal variability in $\mathrm{C}: \mathrm{N}$ ratios estimated from dark ${ }^{14} \mathrm{CO}_{2}$ assimilation without enrichment for three size groups $(A)$ and ammonium and phosphorus concentration $(B)$ in Kāne'ohe Bay during the period from 16 June 1988 to 3 May 1989. When [C:N ratio] with enrichment was higher than $[\mathrm{C}: \mathrm{N}$ ratio] in control, the nutrient limitation index was assumed as unity.

the 0.2 - to $2.0-\mu \mathrm{m}$ size fraction consisted primarily of prokaryotic microalgae and that the 10 - to $35-\mu \mathrm{m}$ size fraction contained most of the diatoms and dinoflagellates (Murphy 1972, Landry et al. 1984).

Transport rates are a function of substrate concentrations (Dugdale 1977), and Wheeler and McCarthy (1982) indicated that ammonium transport rates are substrate limited at ambient concentrations less than $5 \mu \mathrm{M}$ for natural phytoplankton populations in Chesapeake Bay. The ambient ammonium concentrations of 1-2 $\mu \mathrm{M}$ in Kāne'ohe Bay should have been saturating for the picoplankton but may have been limiting for the $10-$ to $35-\mu \mathrm{m}$ size group. Consistent with this scenario is the fact that the percentage of carbon allocated to protein by the pico- plankton did not change in response to ammonium enrichment but increased by a factor of $35 / 31=1.13$ in the $10-$ to $35-\mu \mathrm{m}$ size fraction.

Chemoautotrophic ammonium-oxidizing bacteria may contribute to the incorporation of ${ }^{14} \mathrm{C}$ into protein in the $<2 \mu \mathrm{m}$ size fraction (Dodds and Priscu 1991). However, in our study dark protein synthesis normalized to chl $a$ was not significantly different in the picoplankton and 2- to $10-\mu \mathrm{m}$ size fractions. We interpret these results to imply that chemoautotrophic assimilation of ${ }^{14} \mathrm{CO}_{2}$ was probably insignificant in our studies. Probyn et al. (1990) likewise reported no significant bacterial dark protein synthesis in the $<2 \mu \mathrm{m}$ fraction. The rationale for using $\mathrm{C}: \mathrm{N}$ ratios calculated from dark incorporation of ${ }^{14} \mathrm{CO}_{2}$ 


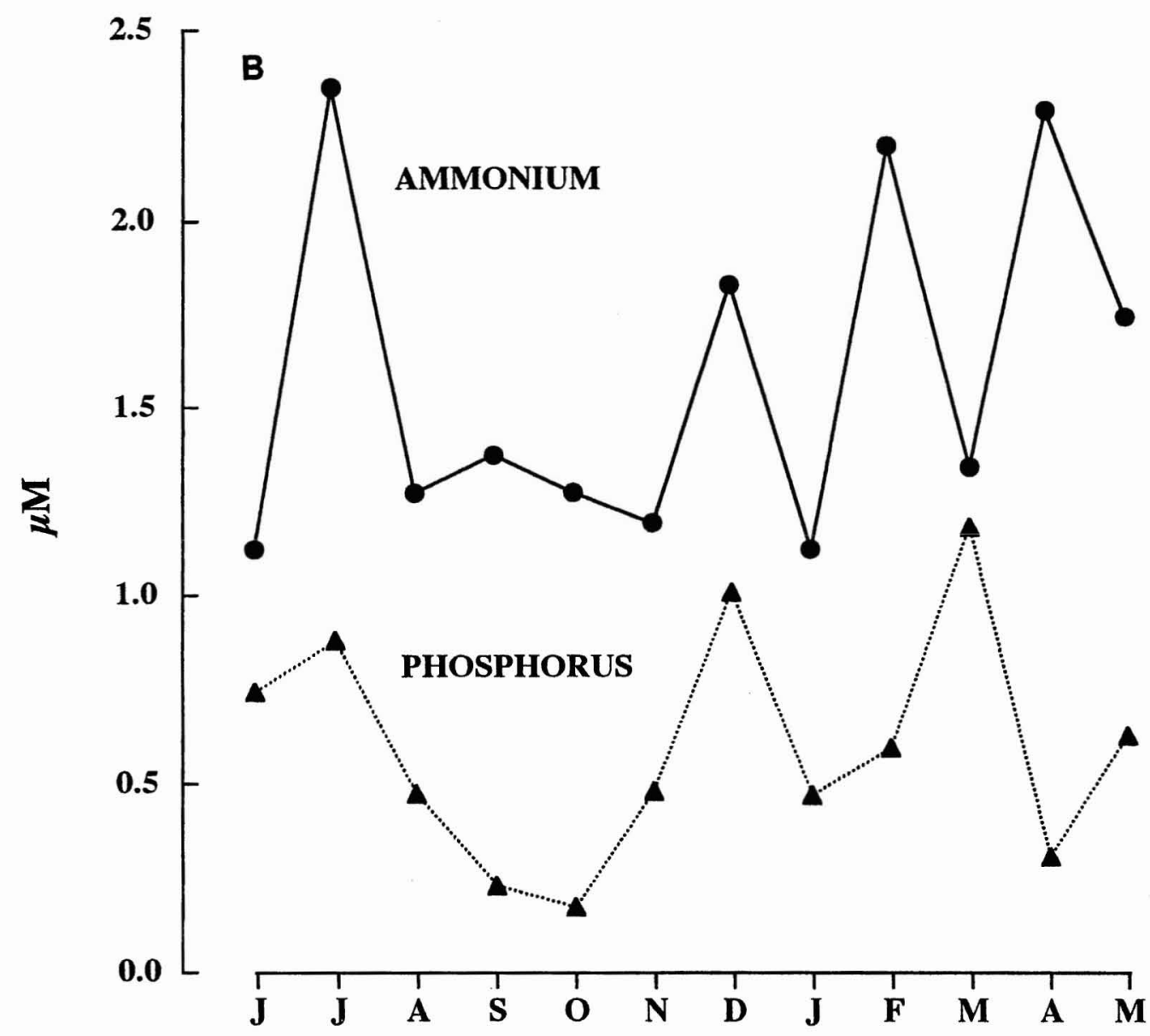

\section{MONTH}

Figure 4. (Continued)

into protein as a measure of the nutritional status of phytoplankton stems from the seminal work of Goldman (1980) concerning $C: N$ ratios and the concept of relative growth rate; the studies of DiTullio and Laws (1986), who developed a method to measure phytoplankton $\mathrm{C}: \mathrm{N}$ ratios in the field based on ${ }^{14} \mathrm{C}$ incorporation into protein; and the work of Morris et al. (1971), Yentsch et al. (1977), and Goldman and Dennett (1983) concerning the relationship between nutritional status and the stimulation of dark ${ }^{14} \mathrm{CO}_{2}$ uptake by nutrient additions.
In this study we have defined the nutrient limitation index (NLI) to be the ratio of the $\mathrm{C}: \mathrm{N}$ ratios of cultures enriched with either ammonium or ammonium plus phosphate to the $\mathrm{C}: \mathrm{N}$ ratios of the control cultures (Figure 5). The NLI defined in this way is identical to the ratio of the percentage of ${ }^{14} \mathrm{CO}_{2}$ incorporated into protein of the control cultures divided by the corresponding percentage for the nutrient-enriched cultures. The NLIs implied by the ammonium plus phosphate additions were about 0.05 lower than the NLIs based on addition of ammonium 
AMMONIUM
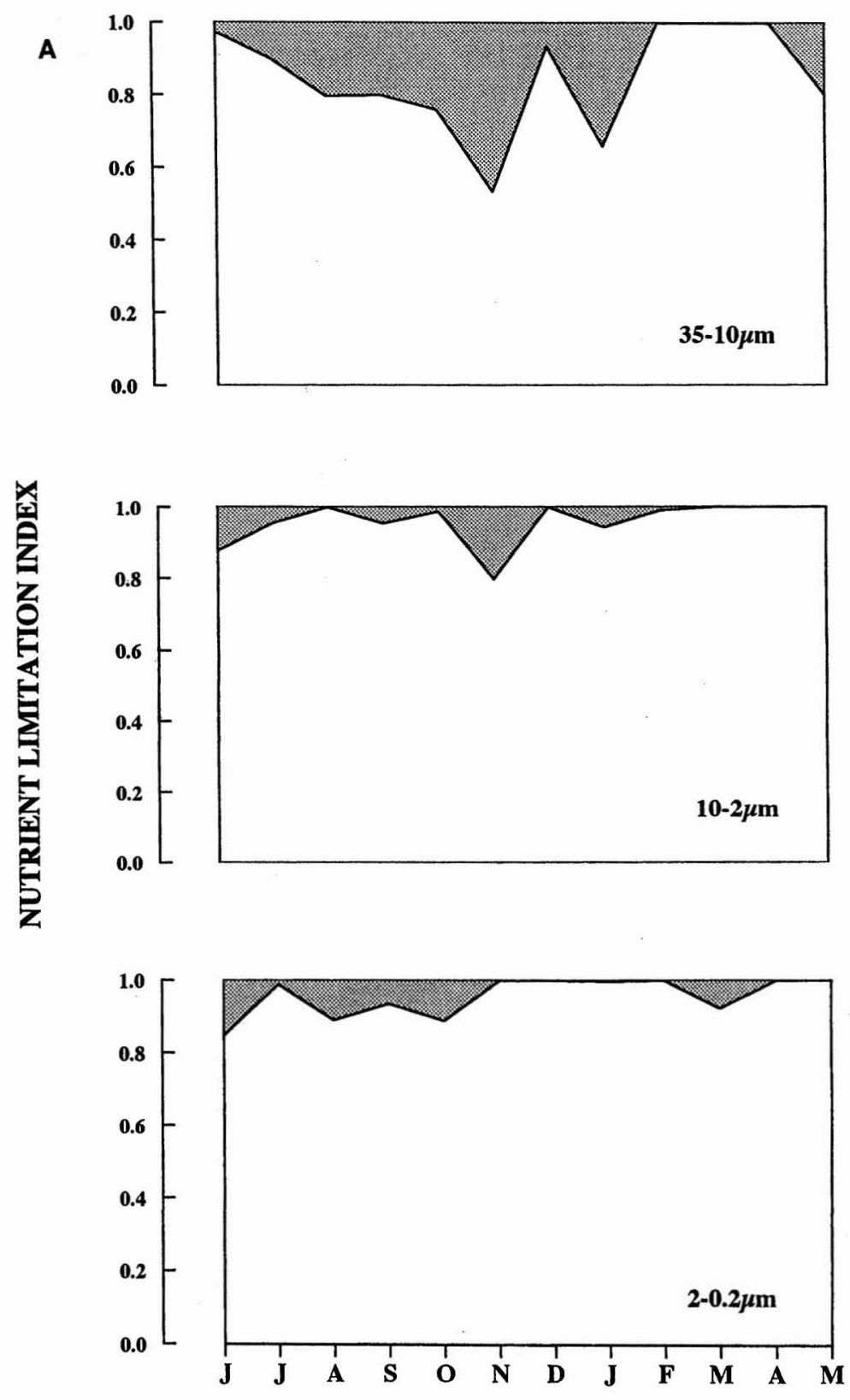

MONTH

FIGURE 5. Seasonal variability of nutrient limitation index for three size groups of phytoplankton with ammonium $(A)$ and ammonium plus phosphorus $(B)$ in Kāne'ohe Bay during the period from June 1988 to May 1989. 


\section{AMMONIUM + PHOSPHORUS}
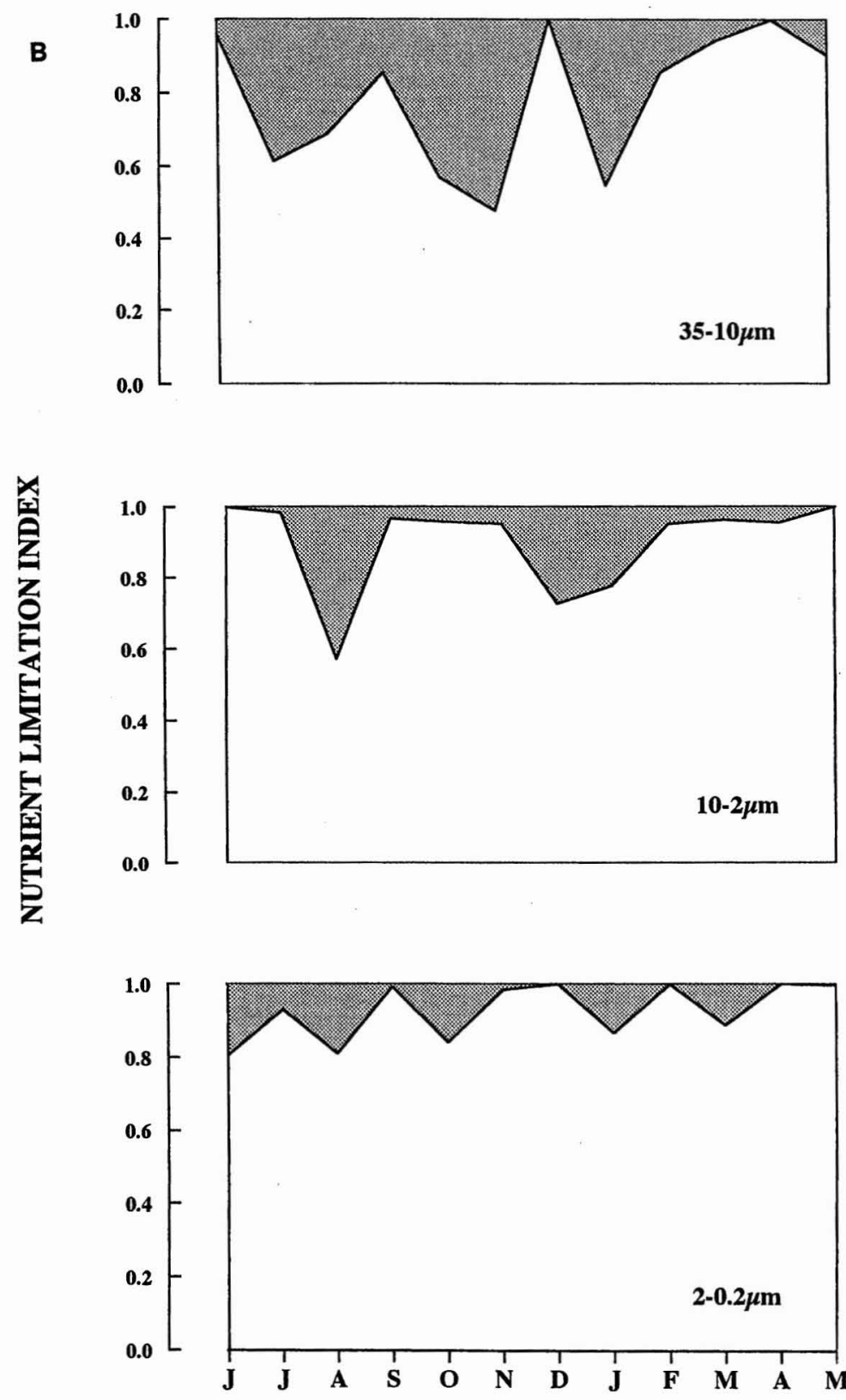

\section{MONTH}

Figure 5. (Continued) 
TABLE 3

Nutrient Limitation Indices for Kān'eohe Bay Phytoplankton $( \pm$ SD)

\begin{tabular}{lcc}
\hline \hline Size range & $+\mathrm{NH}_{4}$ & $+\mathrm{NH}_{4}+\mathrm{PO}_{4}$ \\
\hline $0.2-2.0 \mu \mathrm{m}$ & $0.96 \pm 0.06$ & $0.93 \pm 0.08$ \\
$2.0-10 \mu \mathrm{m}$ & $0.95 \pm 0.06$ & $0.90 \pm 0.13$ \\
$10-35 \mu \mathrm{m}$ & $0.86 \pm 0.15$ & $0.78 \pm 0.19$ \\
\hline
\end{tabular}

only. However, this difference was not significant at $P<0.05$ based on a two-way analysis of variance (ANOVA). In both cases the NLIs imply that the phytoplankton are growing at close to nutrient-saturated rates. This conclusion is consistent with the studies of Laws et al. (1984), who reported the relative growth rate (sensu Goldman 1980) of the phytoplankton community in Kāne'ohe Bay to be 0.74 . Our results show no significant difference between the NLI of the picoplankton and that of the 2- to $10-\mu \mathrm{m}$ size fraction (two-way ANOVA, $P>0.2$ ) (Table $3)$. However, the NLI of the 10 - to $35-\mu \mathrm{m}$ size fraction was significantly different from the NLI of both the picoplankton and the 2to $10-\mu \mathrm{m}$ size fraction $(P<0.05)$. Our work indicates that the growth rates of the picoplankton and 2- to $10-\mu \mathrm{m}$ size fractions were little affected by nutrient limitation and that the larger cells, $10-35 \mu \mathrm{m}$ in size, were the most nutrient limited.

This conclusion is consistent with the theoretical understanding of nutrient transport within the boundary layer around a cell developed by Pasciak and Gavis (1975). Total assimilation of ${ }^{14} \mathrm{CO}_{2}$ and the amount of ${ }^{14} \mathrm{CO}_{2}$ incorporated into protein were lower in the ammonium plus phosphate addition experiments than in the $+\mathrm{NH}_{4}$ experiments. The explanation for the lower assimilation rates in the $+\mathrm{NH}_{4}+\mathrm{PO}_{4}$ experiments probably reflects the metabolic costs associated with nutrient uptake and assimilation. Because the experiments were conducted in the dark, the only energy source to support nutrient assimilation was respiration. Simultaneous uptake of two nutrients is more costly than uptake of a single nutrient. This fact could also explain why the percentage of ${ }^{14} \mathrm{CO}_{2}$ incorporated into protein tended to be higher in the $+\mathrm{NH}_{4}+\mathrm{PO}_{4}$ experiments, although the difference was not statistically significant. Protein is not normally a substrate for respiration. The low-molecular-weight intermediate pool was apparently catabolized to provide the energy needed to assimilate both ammonium and phosphate.

In summary, the response to nutrient additions of the dark incorporation of ${ }^{14} \mathrm{CO}_{2}$ into protein appears to be a useful modification of the methodology developed by Morris et al. (1971), Yentsch et al. (1977), and Goldman and Dennett (1983) for studying major nutrient limitation in phytoplankton. The principal advantage of focusing on the percentage incorporation into protein (or equivalently the $C: N$ ratio calculated from our equation) is the fact that this approach appears to filter out artifacts associated with total ${ }^{14} \mathrm{CO}_{2}$ uptake (e.g., Figures 1 and 2). C:N ratios show virtually the same relationship with growth rate under nitrogen or phosphorus limitation (Laws and Bannister 1980). It is unclear whether this same approach will prove useful for studying iron limitation, a subject of much current interest (Kolber et al. 1994, Lindley and Barber 1998).

\section{Literature Cited}

Allen, C. B., J. Kanda, and E. A. Laws. 1996. New production and photosynthetic rates within and outside a cyclonic mesoscale eddy in the North Pacific subtropical gyre. Deep-Sea Res. 43:917-936.

Banse, K. 1991. Rates of phytoplankton cell division in the field: Iron enrichment experiments. Limnol. Oceanogr. 36:18861898.

Cook, C. B., G. Muller-Parker, and C. F. D'Elia. 1992. Ammonium enhancement of dark carbon fixation and nitrogen limitation in symbiotic zooxanthellae: Effects of feeding and starvation of the sea anemone Aiptasia pallida. Limnol. Oceanogr. 37:131-139.

Cook, C. B., G. Muller-Parker, and C. D. Orlandini. 1994. Ammonium enhancement of dark carbon fixation and nitrogen 
limitation in zooxanthellae symbiotic with the reef corals Madracis mirabilis and Montastrea annularis. Mar. Biol. (Berl.) 118: 157-165.

Cuhel, R. L., P. B. Ortner, and D. R. S. Lean. 1984. Night synthesis of protein by algae. Limnol. Oceanogr. 29:731-744.

DiTullio, G., and E. A. Laws. 1986. Diel periodicity of nitrogen and carbon assimilation in five species of marine phytoplankton: Accuracy of methodology for predicting $\mathrm{N}$-assimilation rates and $\mathrm{N} / \mathrm{C}$ composition ratios. Mar. Ecol. Prog. Ser. 32:123-132.

Dodds, W. K., and J. C. Priscu. 1991. Ammonium stimulation of dark carbon fixation as an indicator of nitrogen deficiency in phytoplankton: Potential errors caused by ammonium-oxidizing bacteria. J. Phycol. 27:79-82.

Dortch, Q., and H. Maske. 1982. Dark uptake of nitrate and nitrite reductase activity of a red-tide population off Peru. Mar. Ecol. Prog. Ser. 9:299-303.

Dortch, Q., J. R. Clayton Jr., S. S. Thoresen, J. S. Cleveland, S. L. Bressler, and S. I. Ahmed. 1985. Nitrogen storage and use of biochemical indices to assess nitrogen deficiency and growth rate in natural plankton populations. J. Mar. Res. 43:437-464.

Dugdale, R. C. 1977. Modelling. Pages 789806 in E. D. Goldberg, ed. The sea. Vol. 6. Wiley-Interscience, New York.

Frenette, J.-J., W. F. Vincent, and L. Legendre. 1998. Size-dependent C: $N$ uptake by phytoplankton as a function of irradiance: Ecological implications. Limnol. Oceanogr. 43:1362-1368.

Glibert, P. M., M. R. Dennett, and J. C. Goldman. 1985. Inorganic carbon uptake by phytoplankton in Vineyard Sound, Massachusetts. II. Comparative primary productivity and nutritional status of winter and summer assemblages. J. Exp. Mar. Biol. Ecol. 86:101-118.

Goldman, J. C. 1980. Physiological processes, nutrient availability, and the concept of relative growth rate in marine phytoplankton ecology. Pages 179-194 in P. G. Falkowski, ed. Primary productivity in the sea. Plenum, New York.
Goldman, J. C., and M. R. Dennett. 1983. Effect of nitrogen source on short-term light and dark $\mathrm{CO}_{2}$ uptake by a marine diatom. Mar. Biol. (Berl.) 76:7-15.

1986. Dark $\mathrm{CO}_{2}$ uptake by the diatom Chaetoceros simplex in response to nitrogen pulsing. Mar. Biol. (Berl.) 90:493500.

Goldman, J. C., and P. M. Glibert. 1983. Kinetics of inorganic nitrogen uptake by phytoplankton. Pages 233-274 in E. J. Carpenter and D. C. Capone, eds. Nitrogen in the marine environment. Academic Press, New York.

Granum, E., and S. M. Myklestad. 1999. Effects of $\mathrm{NH}_{4}{ }^{+}$assimilation on dark carbon fixation and $\beta$-1,3-glucan metabolism in the marine diatom Skeletonema costatum (Bacillariophyceae). J. Phycol. 35:11911199.

Harrison, W. G. 1983. Nitrogen in the marine environment: Use of isotopes. Pages 763-807 in E. J. Carpenter and D. C. Capone, eds. Nitrogen in the marine environment. Academic Press, New York.

Healy, F. P. 1979. Short-term responses of nutrient-deficient algae to nutrient addition. J. Phycol. 15:289-299.

Herbland, A., A. Le Bouteiller, and F. Raimbault. 1985. Size structure of phytoplankton biomass in the equatorial Atlantic Ocean. Deep-Sea Res. 32:819-836.

Holm-Hansen, O., C. J. Lorenzen, R. N. Holmes, and J. D. H. Strickland. 1965. Fluorometric determination of chlorophyll. J. Cons. Perm. Int. Explor. Mer 30:3-15.

Kolber, Z. S., R. T. Barber, K. H. Coale, S. E. Fitzwater, R. M. Greene, K. S. Johnson, S. Lindley, and P. G. Falkowski. 1994. Iron limitation of phytoplankton photosynthesis in the equatorial Pacific Ocean. Nature (Lond.) 371:145-149.

Landry, M. R., L. W. Haas, and V. L. Fagerness. 1984. Dynamics of microbial plankton communities: Experiments in Kaneohe Bay, Hawaii. Mar. Ecol. Prog. Ser. 16:127-133.

LaRoche, J., and W. G. Harrison. 1987. Compartmental models of nitrogen cycling in tropical and temperate marine envi- 
ronments. Mar. Ecol. Prog. Ser. 38:137149.

Laws, E. A. 1984. Analytic models of $\mathrm{NH}_{4}{ }^{+}$ uptake and regeneration experiments. Limnol. Oceanogr. 30:1340-1350.

Laws, E. A., and T. T. Bannister. 1980. Nutrient and light-limited growth of Thalassiosira fluviatilis in continuous culture, with implications for phytoplankton growth in the ocean. Limnol. Oceanogr. 25:457-473.

Laws, E. A., D. G. Redalje, L. W. Haas, P. K. Bienfang, R. W. Eppley, W. G. Harrison, D. M. Karl, and J. Marra. 1984. High phytoplankton growth and production rates in oligotrophic Hawaiian coastal waters. Limnol. Oceanogr. 29:1161-1169.

Laws, E. A., W. G. Harrison, and G. R. DiTullio. 1985. A comparison for nitrogen assimilation rates based on ${ }^{15} \mathrm{~N}$ uptake and autotrophic protein synthesis. Deep-Sea Res. 32:85-95.

Lindley, S. T., and R. T. Barber. 1998. Phytoplankton response to natural and experimental iron addition. Deep-Sea Res. (Topical Studies in Oceanography) 45:1135-1150.

MacIsaac, J. J., and R. C. Dugdale. 1969. The kinetics of nitrate and ammonium uptake by natural populations of marine phytoplankton. Deep-Sea Res. 16:45-57.

. 1972. Interactions of light and inorganic nitrogen in controlling nitrogen uptake in the sea. Deep-Sea Res. 19:209-232.

McCarthy, J. J. 1980. Nitrogen and phytoplankton ecology. Pages 191-233 in I. Morris, ed. The physiological ecology of phytoplankton. Blackwell Scientific Publications, Oxford.

McCarthy, J. J., C. Garside, and J. L. Nevins. 1999. Nitrogen dynamics during the Arabian Sea Northeast Monsoon: A coupled ocean land atmosphere system. Deep-Sea Res. (Topical Studies in Oceanography) 46:1623-1664.

Menzel, D. W., E. M. Hulbert, and J. H. Ryther. 1963. The effects of enriching Sargasso Sea water on the production and species composition of the phytoplankton. Deep-Sea Res. 10:209-219.

Morris, I., C. M. Yentsch, and C. S. Yentsch.
1971. The physiological state with respect to nitrogen of phytoplankton from lownutrient subtropical water as measured by the effect of ammonium ion to dark carbon dioxide fixation. Limnol. Oceanogr. 16:568-589.

Mortain-Bertrand, A., C. Descolas-Gros, and H. Jupin. 1988. Pathway of dark inorganic carbon fixation in two species of diatoms: Influence of light regime and regulator factors on diel variations. J. Plankton Res. 10:199-217.

Murphy, C. 1972. An annual cycle of phytoplankton populations in Kaneohe Bay. M.S. thesis, University of Hawai'i at Mānoa.

Murphy, J., and J. P. Riley. 1962. A modified single solution method for the determination of phosphorus in natural waters. Anal. Chim. Acta 27:31-36.

Pasciak, W. J., and J. Gavis. 1975. Transport limited nutrient uptake rates in Ditylum brigbtwellii. Limnol. Oceanogr. 20:604617.

Probyn, T. A., H. N. Waldron, and A. G. James. 1990. Size-fractionated measurements of nitrogen uptake in aged upwelled waters: Implications for pelagic food webs. Limnol. Oceanogr. 35:202-210.

Solorzano, L. 1969. Determination of ammonia in natural waters by the phenolhypochlorite nethod. Limnol. Oceanogr. 14:799-801.

Taguchi, S., and E. A. Laws. 1987. Patterns and causes of temporal variability in the physiological condition of the phytoplankton community in Kaneohe Bay, Hawaii. J. Plankton Res. 9:1143-1157.

Thomas, R. J., C. R. Hipkin, and P. J. Syrett. 1976. The interaction of nitrogen assimilation with photosynthesis in nitrogendeficient cells of Cblorella. Planta (Berl.) 133:9-13.

Wheeler, P. A. 1983. Phytoplankton nitrogen metabolism. Pages 309-346 in E. J. Carpenter and D. C. Capone, eds. Nitrogen in the marine environment. Academic Press, New York.

Wheeler, P. A., and J. J. McCarthy. 1982. Methylammonium uptake by Chesapeake Bay phytoplankton: Evaluation of the use of the ammonium analogue for field up- 
take measurements. Limnol. Oceanogr. Yentsch, C. M., C. S. Yentsch, and L. R. 27:1129-1140.

Wood, E. D. F., A. J. Armstrong, and F. A. Richards. 1967. Determination of nitrate in seawater by cadmium-copper reduction to nitrite. J. Mar. Biol. Assoc. U. K. 47:2331.

Strube. 1977. Variations in ammonium enhancement, an indication of nitrogen deficiency in New England coastal phytoplankton populations. J. Mar. Res. 35:537555. 